\title{
The Minimill Story
}

JOHN R. STUBBLES

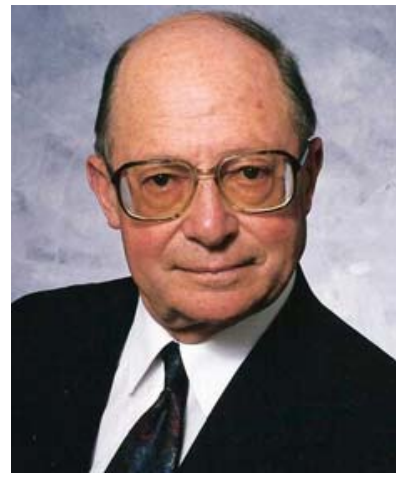

In our efforts to characterize and improve the performance of an existing steelmaking process or in our quest to generate useful knowledge as a basis for the development of new manufacturing routes, measurements and models should be considered as two interdependent requirements. Without measurements, our models are incomplete and unsatisfactory. Without models, we fail to realize, or perhaps even comprehend, the potential significance of our measurements. Sometimes in our enthusiasm, we construct sophisticated elegant models and forget the reality of the actual manufacturing process. In this computer age, we need to remember again the importance of observations and accurate measurements. In addition, as engineers and applied scientists, we have an obligation and a responsibility to facilitate the transfer of new knowledge into the realm of operating practice. During this process of generation, evaluation, and communication of new knowledge, the knowledge exchange step is perhaps the most difficult. In this context, the preeminent aim of collaborative activities between our educational institutions, industrial organizations, government funding agencies, and professional societies is to ensure the availability of high-quality people who not only understand the fundamental aspects and practical implications of their discipline, but also are fully equipped with the essential skills of communication that will enable them to participate throughout their career in this most challenging and satisfying activity, the science and technology of steelmaking.

DOI: $10.1007 / \mathrm{s} 11663-008-9216-9$

(C) The Minerals, Metals \& Materials Society and ASM International 2009

JOHN R. STUBBLES, Steel Industry Consultant, is with the 6325 Lake Front, Mason, OH 45040. Contact e-mail: john_stubbles@ msn.com

The Brimacombe Memorial Lectureship was established in 1999 by the Process Technology Division of the Iron \& Steel Society to honor Dr. J. Keith Brimacombe's outstanding accomplishments in the area of process metallurgy, his dedication to the steel industry, and his profound effect on people in the industry; and also to acquaint members, students, and engineers with the many exciting opportunities that exist in the area of process metallurgy and to inspire them to pursue careers in this field.

John Stubbles was educated in England, receiving a B.Sc. $\left(1^{\text {st }}\right.$ Class Hons.) in metallurgy from the University of Manchester in 1954 and a Ph.D. in Extractive Metallurgy from London University in 1957. After six years in academia, he joined the Youngstown Sheet and Tube Company and for the next 30 years, managed technical activities at several integrated steel companies. In 1993, he joined a mini-mill, Charter Steel, to manage their environmental program. In 1999, he retired to become a private consultant to the industry and to the U.S.
Department of Energy. He has been active in ISS/AIST for nearly fifty years (Distinguished Member in 1984, Elliott Lecturer in 1995, Howe Lecturer in 1997, and Brimacombe Lecturer in 2006). He is married with three sons, and hobbies include golf, the history of iron and steelmaking, and watercolor painting.

\section{INTRODUCTION}

SOME of us were privileged to know Keith Brimacombe (Figure 1). The numerous national and international awards and honors that were bestowed on him during his career clearly stamped him as an outstanding technologist and administrator in both ferrous and nonferrous process metallurgy. However, they fail to humanize him. He was urbane, witty with a twinkle in his eye, and infectiously enthusiastic about his work. 


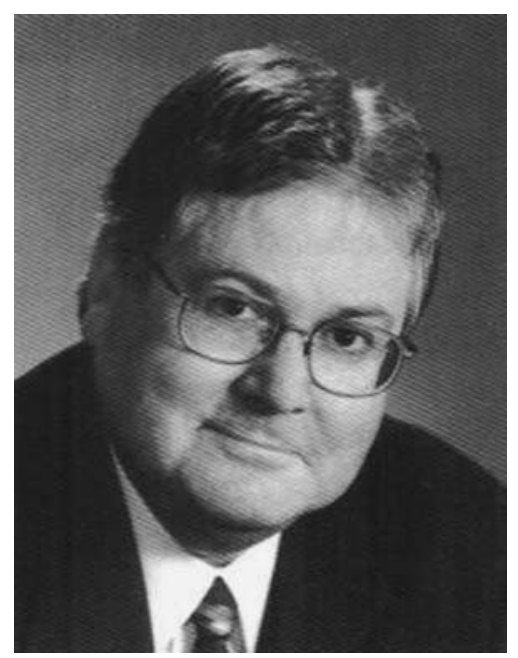

Fig. 1-Keith Brimacombe (1943-1997).

You would leave any meeting with him pumped up. He also had the common touch, and was perfectly comfortable drinking beer in a pub with the guys from the shop floor after a day in the mill. On the steel side, the minimills, in fact, were his external laboratory, where ideas from the University of British Columbia (UBC) about continuous casting were put to real-world tests and modified as field results dictated. The educational casting course developed by him at UBC in the early 1980s was attended by hundreds of steel industry personnel over the years, and became "Mecca" for instruction and the exchange of ideas about the continuous casting of billets in particular. In my opinion, this course played a significant role in stimulating technological improvements in the long products sector of the steel industry and fostered healthy competition between the minimills. The first four Brimacombe lecturers were all distinguished academics who could expound on erudite research topics. I do not have that luxury. However, I do love history, and from random conversations, I know that few people are aware of how the minimill business really got started and developed in North America. Therefore, I have opted in this lecture to review this history, and in so doing, recognize the accomplishments of Keith and other pioneers who, within a generation, opened the door to a new and exciting type of steel industry and a technological revolution that is ongoing.

\section{EARLY DAYS: 1943 TO 1964}

Electric arc furnaces (EAFs) have been around in the United States since 1906. They quickly displaced the inefficient fuel-gorging crucible furnaces, whose annual U.S. output averaged at best about 120,000 tons of "quality" steel. ${ }^{[1]}$ That translated in those days into long heat times, perpetuating the myth that the longer the steel was "cooked," the better its quality. By the outbreak of WWII in 1941, sluggish EAFs were producing less than 2 million tons annually or about half that of the concurrent basic Bessemer process. Growth in the EAF sector was slow and overshadowed by Open Hearth production that had soared to over 60 million annual tons in the same timeframe. However, more steel and particularly alloy steel for armaments was needed for the war effort, and the quickest way to achieve this was to build EAF furnaces. In 1943, the U.S. Government and the Iron and Steel Division of AIME sponsored the first Electric Furnace Conference in Pittsburgh, chaired by Charlie Briggs. ${ }^{[2]}$ This spotlight on the process, coupled with some government funding, encouraged several integrated steelmakers to install EAF capacity and a brief surge in EAF production occurred. After this wartime spike, the process again grew slowly in the postwar period, and EAF steelmaking remained the "poor relation" within the integrated steel plants as open hearth output reached 86 million tons annually by 1950 (Figure 2). However, the production of stainless and high alloy steel remained with the EAFs.

Apart from the initiation of the EF Conference, 1943 was in retrospect an auspicious year for the minimills with respect to people. Keith Brimacombe and Ron Lincoln (more of him later) were born, and Jerry Heffernan (Figure 3) graduated as a metallurgist from the University of Toronto. After a stint in the army in Europe, where he gained experience in project management and handling people, Jerry worked for a year at UBC with Professor Frank Forward (again in retrospect, a far reaching association) on various technical and business assignments. He entered the steel industry via the Westland Iron and Steel Foundry and acquired more steelmaking experience at Western Canada Steel from 1948 to 1954.

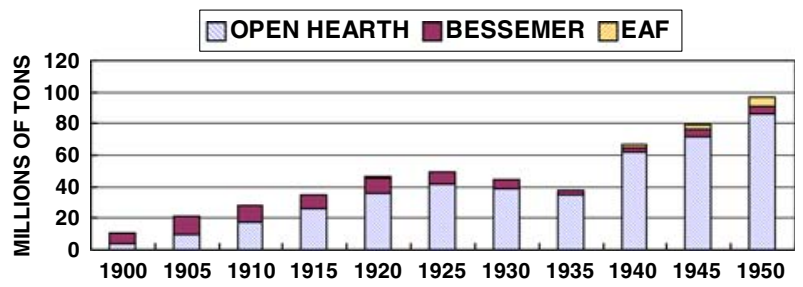

Fig. 2-U.S. raw steel production by process: 1900 to 1950 .

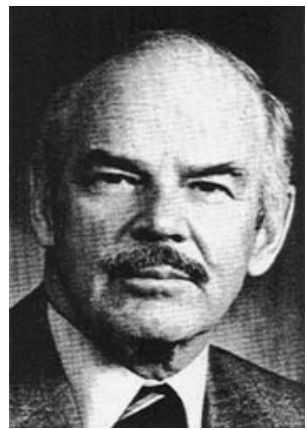

Fig. 3-Jerry Heffernan (1919-present). 
His obsessive drive to improve any given process and apply his inherent entrepreneurial skills enabled him to raise capital for the construction of Premier Steel (later renamed Alta Steel, a historical ASM site) in Alberta in 1954, where he wanted to implement his vision of displacing ingot casting with continuous casting. This was not a new idea-Henry Bessemer's twin roll patent for casting steel (British patent 221) dates back to 1857 - but in subsequent decades, no commercial process for steel had emerged. The technology was developed primarily for the lower melting point nonferrous metals that were easier to handle. In 1921, C.W. van Ranst had proposed harmonic mold oscillation to avoid sticking, but this minimized heat transfer. In 1933, Junghans proposed a fast upstroke but a down stroke that matched the withdrawal speed of the casting. This breakthrough concept worked for brass but not steel where sticking was still an issue. ${ }^{[3]}$ Nevertheless, interest in the continuous casting of steel picked up in Europe and Russia in the late 1940s, and in 1950, Iain Halliday in the United Kingdom came up with the "negative strip concept," where the downward movement of the watercooled copper mold in the cycle slightly exceeded that of the casting. ${ }^{[4]}$ This not only solved the sticking problem, but more significantly, from a commercial standpoint, improved heat transfer that allowed for increased casting speeds. In 1952, at Barrow, a small plant in the United Kingdom, 2-in. square billets were continuously cast from 10-ton batches of steel. Jerry was well aware of this activity but felt that it did not meet his needs. He had met Irving Rossi, who owned Metalcast (New York, NY), and had rights to some of Junghans patents in the United States. Atlas Steel had installed a Rossi/Koppers stainless slab caster as early as 1954. Jerry had a billet caster built by Rossi/Koppers at Premier in 1959 to meet the growing demand for sucker rods in oil-rich Alberta. The ambitious goal was to cast 60,000 tons annually of high-quality carbon steel as 4- and 6-in. square billets from 18-ton batches of liquid steel produced in arc furnaces. ${ }^{[5]}$ Over the next few years, these goals were met at Premier, but most of the steel was still cast into ingots. Meanwhile, Stelco saw a Western market slipping away, and eventually bought Premier from Jerry in 1963. By leveraging this capital, he was able to construct Lasco (Lake Ontario Steel Company) in 1964, ironically right on Stelco's doorstep near Toronto! If we define a "minimill" as one where 100 pet of the output from an EAF shop is continuously cast with no ingot mold backup, then Lasco was the first minimill not only in North America but in the world. Other plants had casters, but none were as committed to the continuous casting process. It is not clear who coined the term "minimill" originally, but it is now essentially obsolete as annual outputs have risen from the original $200,000 / 300,000$ tons to multimillion ton levels.

One of the new hires at Lasco was Dr. Gordon Forward, a UBC graduate who followed postgraduate research with Professors Elliott and Chipman at MIT with 2 years of employment by Stelco. This experience convinced him that conservative "big steel" was not his "cup of tea," to coin a colonial phrase, and with the
UBC links, it was not difficult for Jerry to lure him to the nearby melt shop at Lasco. He soon became general superintendent and was destined to carve his own niche in the minimill world. Although Lasco was a union mill, Jerry was able to introduce a new management philosophy into steelmaking - a limited supervisory hierarchy with emphasis on continuous improvement in all activities. These encompassed not only process improvements, but training, safety, and incentives to involve the workforce constructively. It was McGregor's 1960 "Theory Y" of management put into practice, and another first for the North American steel industry. ${ }^{[6]}$ This minimill "culture" has transformed the North American steel industry and arguably has had more impact on productivity than all but a handful of technical innovations. Figure 4

There were two other technical developments in the 1960s that deserve mention, because they have had a profound impact on both steel quality and productivity. The first was the porous plug, developed by Bob Lee and Etienne Spire at Air Liquide. They published an article in the AIME EF Proceedings of 1951, which showed that liquid calcium aluminate slags could desulfurize steel very effectively by bubbling argon through a porous plug at the bottom of a ladle to promote slag/ metal interaction. ${ }^{[7]}$ The concept was not compatible with nontilting Open Hearth furnaces, where the oxidizing slag inevitably covered the liquid steel at tap, but it could have been used in EAF shops where tilting furnaces allowed for some slag carryover control. Porous plugs were eventually used in tundishes at Lasco, and even in a large ladle in 1970 at Dofasco for stirring (Figure 5). However, the idea of a hole in the bottom of a ladle was a hard sell, and the routine use of plugs in ladle metallurgy was still more than a decade away.

The other development was ladle vacuum arc degassing (VAD), a patent for which was issued in 1968 to Chuck Finkl. He actually used the process at his small Chicago mill, producing large rounds for forging applications ${ }^{[8]} 3$ years before his patent was granted. A VAD was also installed at a minimill, Dunkirk Steel, in 1968.

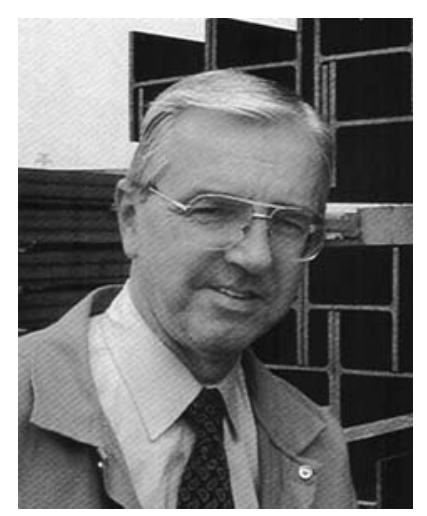

Fig. 4 - Gordon Forward: 1936-present. 


\section{GROWTH: 1964 TO 1975}

Willy Korf (Figure 6) was a German entrepreneur who built a rolling mill at Kehl in 1965, but due to supply problems from the arrogant big steelmakers in Germany, decided to build his own meltshop in $1968 .{ }^{[9]}$ $\mathrm{He}$ had seen the Lasco operation and was convinced that continuous casting was the way to go. He installed a Demag machine with in-line reduction capability so that billets of different sizes could be produced from one mold size. The integrated steelmakers continued to make life difficult for Korf by controlling the price of scrap on which he was totally dependent. In retaliation, Korf "crossed the pond" to build Georgetown Steel in South Carolina in 1969. At this time, scrap in the United States was very cheap ( $\$ 30 /$ ton $)$ due in part to the surging growth of the BOF process. This required less scrap than the Open Hearth and thus changed the economics of the domestic scrap market. Another incentive to enter the steel business was the low capital cost of a minimill of around $\$ 50 /$ ton of annual capacity, a ridiculously low figure relative to that for an integrated

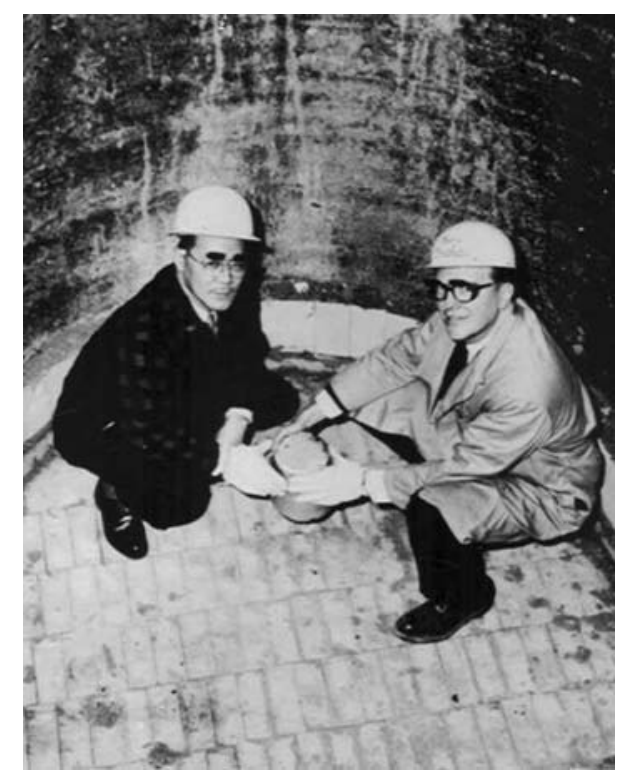

Fig. 5-Bob Lee, Barry Strathdee, DOFASCO-1970.

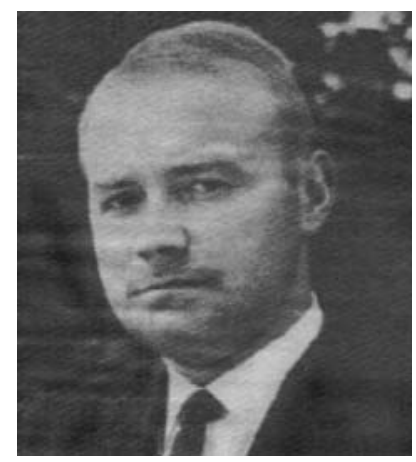

Fig. 6-Willy Korf: 1929-1990. mill. However, Georgetown found scrap was not easy to come by, and soon decided to develop a market for welding wire that required a chemistry (ultra low residuals and nitrogen) that most scrap-based EAFs could not meet. To accomplish this, Korf built a Midland Ross Experimental (Midrex) plant in 1971 to supply a high percentage of the EAF charge as directly reduced sponge iron. It was the second DRI plant in North America, the first being at Oregon Steel, and it preceded Sidbec, Contrecoeur by 2 years. This Ispat Inc. Sidbec plant is still operational.

During his lifetime, Korf promoted several other revolutionary processes such as the energy optimizing furnaces (EOFs), which was a forerunner to the Fuch's shaft furnaces of today, and the ironmaking Corex process that is now linked with a Midrex module at the Suldahna plant in South Africa. The Corex blast furnace supplies iron units to the Conarc process, where a BOF and UHP-EAF are also linked. ${ }^{[10,11]}$ Korf tragically died in a plane crash in 1990 at age 61, a great loss to the international steel industry. AIST has a Memorial Foundation Scholarship in his name. He would be pleased to know that his original steel plant at Kehl, Badische Stahlwerke, is not only one of the most productive EAF steel mills in the world (2.0 million tonnes/yr from two 85 tonne EAFs) but has been an international training ground for many EAF operators. ${ }^{[12]}$

With Lasco running well, Jerry Heffernan had now built a minimill in partnership with Cargill in St. Paul, Minneapolis known as North Star Steel. In this time frame, Ken Iverson, after a series of positions in diverse metal-working and casting companies, became almost by default the President of the struggling Nuclear Corporation, whose only profitable operating unit was the Vulcraft division in Norfolk, NE (Figure 7). When his sole supplier of bar steel for this fabrication plant kept raising prices, Iverson decided to seek other sources of rebar. It was a domestic replay of the Korf situation. The North Star mill was the closest bar mill to Norfolk, and after contact with Jerry Heffernan, Iverson must have had visions of building his own mill to supply his own steel. The teetering Nuclear Corporation was now headquartered in Charlotte, but Darlington, SC was selected as the site for the first steel mill because it was

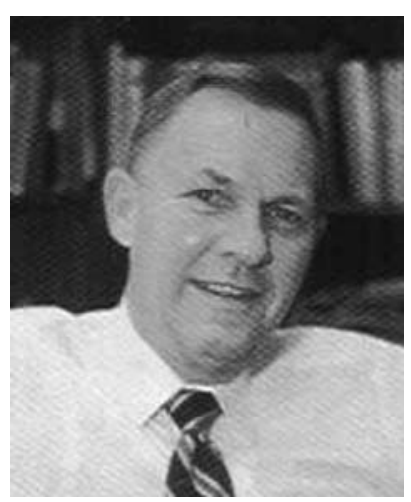

Fig. 7-Ken Iverson: 1926-2002. 
close to a Vulcraft joist plant. The mill was commissioned in 1969 and designed for a modest annual production level of only 200,000 tons.

Learning how to continuously cast steel at Darlington with a "green" crew of farmhands nearly put Nuclear into bankruptcy, but by 1971, experience had been acquired, the bugs had been worked out, and steel sales in 1972 turned Darlington into a "goldmine." The company name was changed to Nucor. Mills at Norfolk (1974) and Jewett, TX (1975) piggy-backed this success. ${ }^{[13]}$ All these mills were also built at rural sites where hard-working farm boys with good mechanical skills and no preconceived ideas about steelmaking were eager to work for a low wage but big bonuses based only on quality tonnage. It was a sure-fire recipe for success as has been proven at many locations throughout the United States since then. It is unlikely that Ken Iverson back in the early 1970s envisioned the Nucor of today with over 25 million tons of capacity and still growing.

However, Jerry Heffernan, the consummate practical visionary, definitely had plans to create a network of mills serving different regional markets. He created Co-Steel International in 1970. Two years previously, he had formed Ferrco to transfer technology not only between his own mills but also around the industry. Almost by accident, he acquired Sheerness Steel in the United Kingdom, a mill famous for decertifying its union and for many technological innovations in later years such as a shaft for scrap preheating and the injection of EAF dust into the furnace. Meanwhile, Cargill acquired control of North Star by buying out minority shareholders. This development irritated Heffernan and his response was to bargain away his shares for a handsome profit. Now he had capital to build the "Jewel in the Crown" of Co-Steel. Plans for Chaparral Steel in Midlothian, TX were drawn up in 1973, and the mill was commissioned in 1975 with a projected annual output of only 220,000 tons. It was managed by Dr. Gordon Forward and owned jointly by Co-Steel and Texas Industries, the cement-producing neighbor across the street. With his strong technical background and a management philosophy honed at Lasco, Gordon turned Chaparral Steel into the model minimill in North America and quickly expanded it to become something special. Employee involvement and training, incentives, safety, recycling of waste products, and the implementation of new technology all received serious attention. Gordon hired Ron Lincoln (Figure 8) from U.S. Steel, Baytown to run the meltshop, and could not have picked a better man. Ron was dynamic in the extreme and pushed the latest technology with enthusiasm. Annual production at Chaparral had soared to an unthinkable 1 million tons by 1984 , and is now over two million. ${ }^{[14]}$ He was also a driving force within the fledgeling ISS Globetrotter Organization, which stressed serious information exchange in an informal setting involving golf, drinking, wives, and "significant others." This activity was seen by many "big steel" executives as a maverick group enjoying junkets in nonsteel locations such as Orlando, Colorado Springs, and Nashville. In reality, it was an ideal forum for the exchange of ideas on practical steelmaking. Tragically,

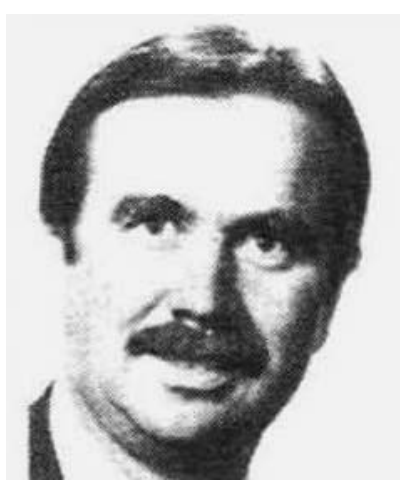

Fig. 8-Ron Lincoln-1943-1989.

Ron was diagnosed with cancer in the mid 1980s and died in 1989. He will never be forgotten by those who knew him, and the Iron and Steel Society (now AIST) created a Foundation Memorial Scholarship in his name.

By 1975 , the $30+$ minimills in the United States and 8 more in Canada spanned the continent and produced about 6 million tons annually of bar and section products. From the perspective of big steel, they were not particularly threatening-long product markets were being eroded but the flat rolled markets were clearly safe! The integrated mills had other problems to worry about. The Clean Air Act (1970) and Clean Water Act (1972) followed on the heels of OSHA and were to be followed by RCRA in 1976. These mandated heavy capital expenditures and increased operating costs to meet environmental and safety regulations, and impacted the integrated mills to a far greater extent than the minimills. Imports were rising, unions were belligerent, pensions had to be funded, and while 1973 remains the record year for raw steel production in the United States, it was also the year of the first oil crisis. The delayed economic impact of this was felt in 1975 as shipments dropped by 20 pct with the brunt of the reduction taken by the integrated mills. It was a body blow from which "big steel" never fully recovered. Figure 9 shows the breakdown of raw steel production by process in the United States between the creation of Lasco in 1964 and Chaparral in 1975. The Open Hearth Process was being displaced by the basic oxygen process. Slab casting had not caught on yet, although in all fairness, U.S.S. (Gary), Weirton, and McLouth Steel all operated million ton a year slab casters as early as 1970 . Nonminimill EAF production was far greater than that of the minimills.

\section{TECHNICAL MATURITY - 1975 TO 1989}

To compete in the global economy, the U.S. steel industry had to improve both yields and quality. Yields from 1910 to 2000, as defined by AISI statistics on shipments/raw steel production, are shown in Figure 10. Until around 1980, yield numbers hovered around $72 \pm$ 2 pct, which required the production of a lot more raw 


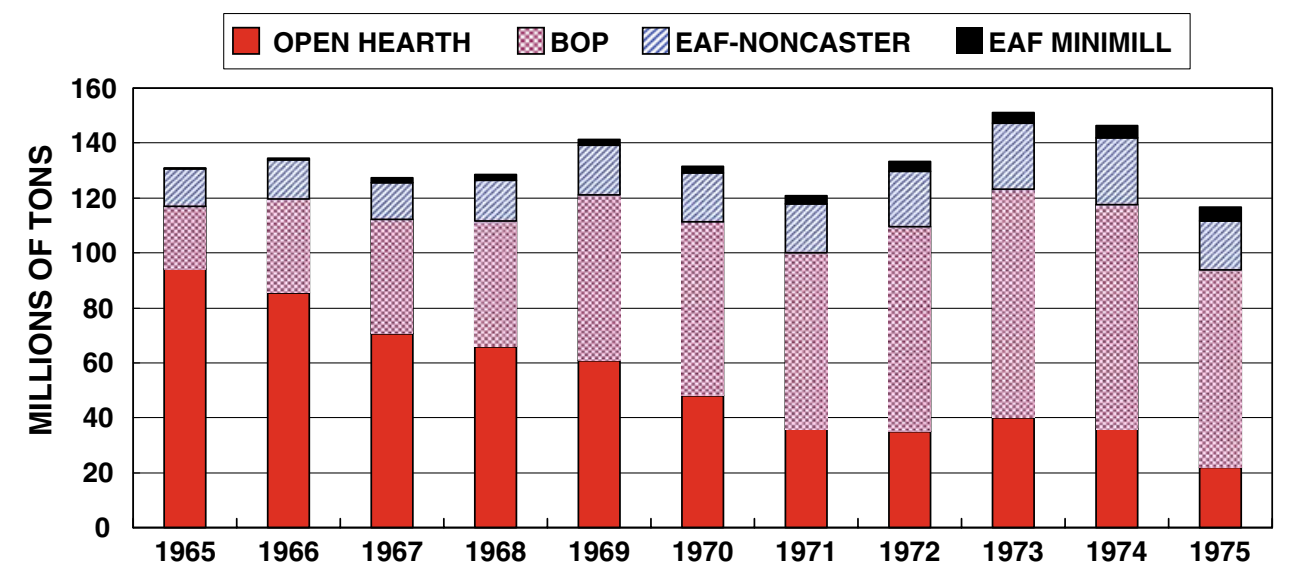

Fig. 9-U.S. raw steel production by process: 1964-1975.

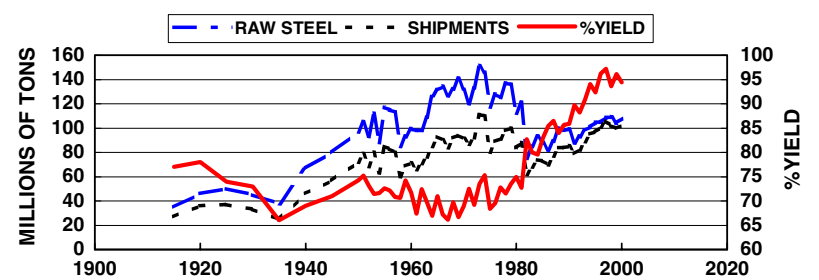

Fig. 10-U.S. steel industry 1910 to 2000. Yields, raw steel, and shipments (AISI).

steel to meet shipments than is the case today. The latest data are a little deceptive since semifinished steel imports (slabs, billets) have increased in recent years and can explain why, overall, raw steel/shipments are now unrealistically close to a $1 / 1$ ratio.

The minimills were looking to move up the quality chain and produce more profitable value added products, while the integrated mills collaborated with the Japanese steelmakers to install slab casting machines and maintain their share of the domestic auto market. The installation of continuous casters not only increased U.S. raw steel yields dramatically, as shown in Figure 11, but resulted in less downstream scrap because the semifinished steel was of higher quality.

Meanwhile, the EAF-based minimills have introduced many technologies to increase their melting efficiency. Water-cooled panels and roofs had long displaced brick in most areas above the slag line. Initially, this was a move to increase shop capacity by avoiding frequent relines, but there were cascading benefits. It was realized that higher power levels could now be handled and, even more significantly, that if slag could be made to foam and surround a long instead of a short arc, electrical efficiency could be significantly improved. Increasingly powerful transformers were installed, and the introduction of more chemical energy by carbon oxidation and natural gas combustion to supplement $\mathrm{kWh}$ became routine. These developments minimized power-on time. To address power-off time, new types of tap holes were designed, devices to speed up electrode changing were installed, and maintenance delays were minimized.

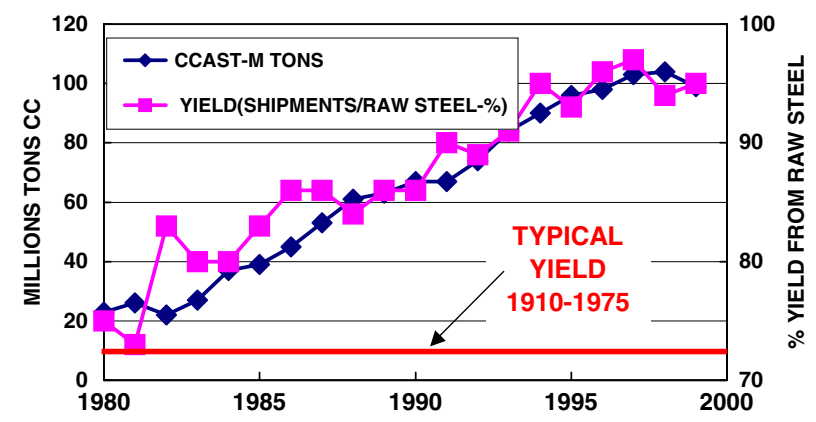

Fig. 11-Impact of continuous casting on U.S. steel industry yield (AISI).

Direct current (DC) furnaces made their appearance but had only a marginal impact on productivity. Then came ladle furnaces, with and without vacuum capability, to establish a buffer between the EAF and the caster. The ultra high powered, efficient EAFs were now able to focus on fast melting, while the final chemistry, temperature, and cleanliness of the liquid steel prior to casting were controlled in the ladle furnaces. At the continuous casters, the focus was on stream shrouding, nozzle clogging, tundish design, oscillation patterns, mold design and instrumentation, EMS, mold lubrication, and spray configurations. All were subjected to pragmatic technical analysis, most notably from the Canadian Universities - the UBC group under Keith Brimacombe published an article every year from 1980 onward on casting variables affecting billet quality. His 1993 Howe Memorial lecture encapsulates many of his ideas. ${ }^{[15]}$ The minimills could now produce a wide range of long products from rebar to selected bearing steels. Manhours per shipped ton were often below 2. Energy per liquid steel ton for 100 pct cold scrap charges was down to around 550 equivalent $\mathrm{kWh}$, of which $80 \mathrm{pct}$ was inevitably locked in as sensible heat in the liquid steel and associated slag (Figure 12).

In the 1980s, the minimills raised the bar on long product quality and productivity, made money, and kept growing. Further, in 1988, Jim Collins (Figure 13) broke 


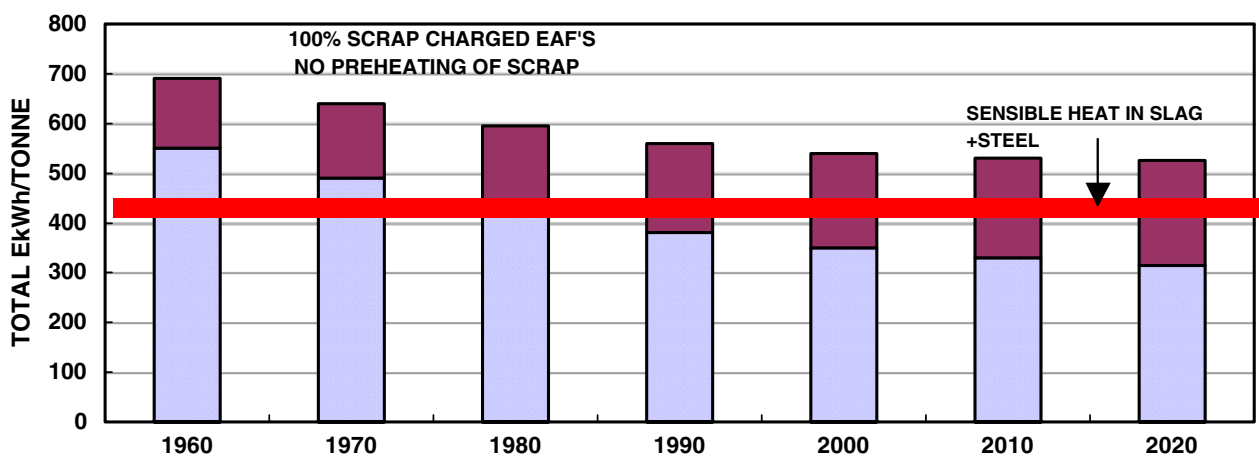

Fig. 12-Trends in energy consumption by EAFs.

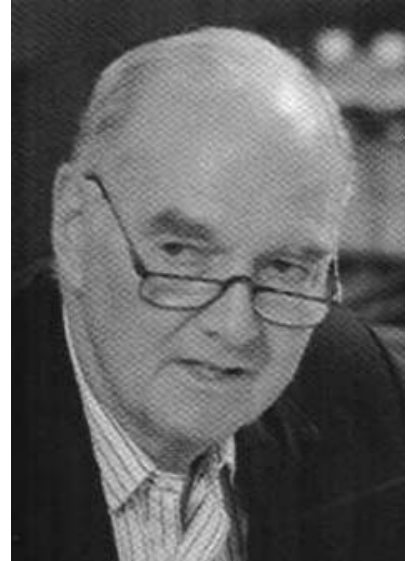

Fig. 13-Jim Collins-1927-present.

away from AISI and established the Steel Manufacturers Association, a political voice in Washington for the minimills. This lean, no-frills organization mirrored the management structure of the minimills themselves and is now directed by Tom Danjczek, a dynamic ex-steelmaking operator and executive.

\section{BREAKTHROUGH: 1989 TO 2005}

Personnel from the minimills are real globetrotters, and scour the world for new relevant technologies. There are no formal research facilities in these companies, but as Gordon Forward has said, there was emphasis on little " $r$ " and big " $D$." The lean management hierarchy accelerates the evaluation and implementation of foreign as well as "homegrown" ideas. It was no secret that the SMS group in Germany had been operating a pilot-scale thin slab casting operation for several years in the 1980s. The facility had been visited by numerous groups from the United States, including some from the major steel companies. However, Ken Iverson of Nucor had the guts to abandon a \$5 million investment on the Hazelett belt machine at Darlington and install the SMS thin slab caster in the cornfields of Indiana at Crawfordsville. The year was 1989 and the commissioning of this compact strip process (CSP) qualifies as a turning point in our industry, in my opinion ranking with Bessemer's process in 1856 and the John Tytus continuous rolling mill at Ashland in 1924. Ken Iverson revolutionized the U.S. steel industry with his gutsy decisions, not all of which panned out. Tragically, in 1997, his health deteriorated and he died in 2002 after a protracted illness. He was a legend in his own time.

In the CSP, a single strand caster with a special mold produces a continuous 52-in.-wide strand of 2-in.-thick steel, which is sheared hot and fed to an in-line tunnel furnace for temperature equalization. The thin slabs are then fed directly into the rolling mill. This is essentially continuous steelmaking, with two key buffers, the ladle furnace, and the tunnel furnace. The hard work and heartache required to produce quality sheet steel with this process has been chronicled in detail, and the chorus of gloom and doomers ("they will never produce auto quality steel") were again proven wrong. ${ }^{[13]}$ By this time, the Blythville structural mill, a joint venture of Nucor with Yamato Steel and commissioned in 1988, was running exceptionally well, and Crawfordsville amazingly turned a profit within a year. Nucor built a second and even more productive mill at Hickman (two million tons per year in 1995, 2 years after commissioning) before anyone else in the United States put their hat in the ring. This mill had seven hot mill stands and was fed by two parallel casters to optimize hot mill productivity. It was even possible to roll thinner cold-rolled gages off the hot mill, but this slowed productivity and was not economic. Once the floodgates opened, "greenfield" sites producing sheet, plate, and structural products were built all over the United States (Figure 14). Between 25 and 30 million tons of capacity for these products alone has been added since 1990 at a capital cost of about $\$ 300 /$ annual ton to offset the millions of tons of integrated capacity that was closed down. These are annual multimillion ton mills and, thus, render the term "minimill" obsolete. It is also important to recognize that all EAF plants are very flexible relative to productivity, and have been able to surpass planned melting capacity with ease by upgrading transformers, 


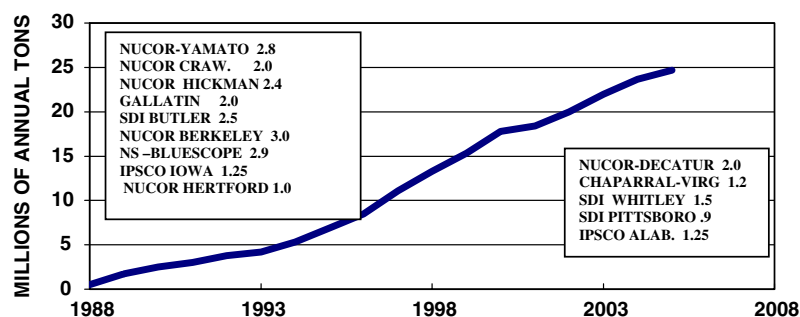

Fig. 14 -Major U.S. EAF Greenfield installations since 1988.

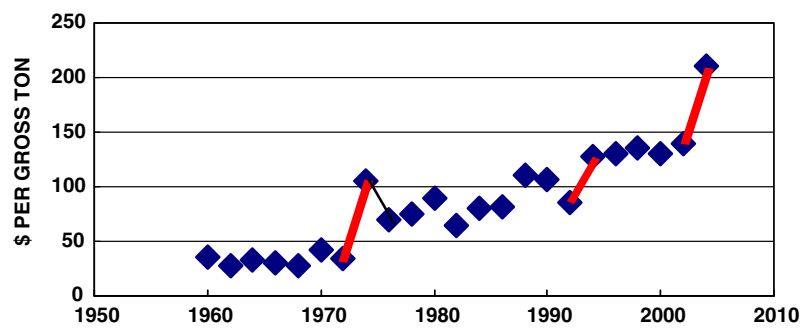

Fig. 15-AMM data on no. 1 average annual heavy melt prices in the United States.

using more chemical energy and squeezing down poweroff time.

It was now possible to charge and melt scrap, cast, roll in-line to hot band, and put coils or plate on a truck in a few hours. Energy requirements and greenhouse gas emissions per ton were the lowest in the world, while manpower was reduced to the unheard of level of under 1 per ton. Now that Nucor Berkeley has installed VOD facilities for the production of ultra low carbon steels, tinplate and special electrical steels remain the only untouched flat-rolled products not targeted by these new EAF plants, while they dominate plate, structural, and rail production in the United States. ${ }^{[16]}$

The other interesting feature of these mills is their diversity with respect to equipment. It is obvious that further reductions in energy /ton at the $\operatorname{EAF}$ (i.e., more productivity) can only be achieved by charging hot iron units. Shaft furnaces and Consteel capture heat from the hot waste gases so that some of the scrap is preheated. ${ }^{[17,18]}$

Prime scrap availability and pricing are two potential concerns for the minimills. The sharp and unanticipated jumps in average no. 1 heavy melt scrap pricing shown in Figure 15 only tell half the story. Spikes for prime scrap on a monthly basis have been as high as $\$ 400 /$ ton in recent years. Ironically, domestic industry profits have historically tracked scrap prices for years, because scrap is expensive when steel is in demand and sells well. That could change if external factors (scrap exports and AI imports such as Brazilian charcoal "pig" iron) start to play a major role in scrap market economics. Attention has therefore been directed once again to producing alternative iron (AI) products domestically to supplement scrap. About 76 million tons of steel scrap are recycled in the United States annually, thanks to major auto shredding programs and the efficient recycling of other consumer goods. Direct reduction processes using natural gas are not economically viable in the United States - coal has to be the reductant. The recent Mesabi pilot development, the Kobe-Midrex ITmk3 process, has produced iron "nuggets" such as $\mathrm{M}$ and M's, which appear to be an ideal AI feed material. ${ }^{[19]}$ Plans for two full-scale plants are in the works, one on-site at Steel Dynamics, Inc., Butler and the other in Minnesota. The on-site plant could feed hot nuggets or even liquid iron to the EAF. The objective of another development, HISmelt, is to produce liquid iron directly from coal, oxygen, and iron oxide. ${ }^{[20]}$ This project has been in the pilot plant stage for many years and shares some features of the abortive AISI Direct Steel process. An 880,000 ton a year plant is now being built in Kwinana, Australia by a consortium of companies including Nucor. The latest twist in the United States is the conversion of an integrated plant, Wheeling Pittsburgh, into an EAF mill with the Consteel heat recovery process and the capability of charging hot metal from a remaining blast furnace. ${ }^{[17]}$ There are literally dozens of ideas floating around the EAF-AI sector to optimize energy consumption and productivity by redesigning furnaces to be flexible relative to raw materials, using different electrode configurations, and of course installing sensors and computer feedback controls where practicable. All these developments have been reviewed in detail in the latest edition of that steel industry "bible," Making, Shaping, and Treating Steel. Will plasma or induction melting ever find a niche in melting? The final chapters on melting steel with electricity as the secondary energy source and coal as the primary energy source have yet to be written. Beyond melting, the casting of "near net shape" wide flange beams by Chaparral is an example of how "thinking out of the box" engineering has increased productivity while reducing energy consumption per ton. The tunnel furnaces in CSP mills have cut conventional reheating energy by 50 pct. The Nucor development (Castrip) at Crawfordsville has reached commercial status and is being watched with great interest. ${ }^{[21]}$ Will this usher in the era of the micromill?

Meanwhile, both the integrated and EAF sectors have undergone major restructuring over the last 5 years. Nucor has acquired several new mills to add to its own stable and is now one of the largest domestic steelmakers with a capacity of well over 25 million tons. Other minimill groupings - Ipsco, SDI, CMC, and AmeristeelGerdau - account collectively for many of the original minimills. Independents are becoming a rarity. The spread of EAF facilities in the United States stimulated in the first place by Lasco in Canada is shown in Figure 16.

Mittal Steel and U.S. Steel now have the lions share of integrated capacity in the United States, while in Canada, Dofasco has both modern EAF and BOF capacity and is a model integrated mill but is now part of a European consortium. The EAF sector in the United States now ships more tonnage than the integrated mills and this transition will continue (Figure 17). For the record, Lasco was commissioned exactly 100 years after the original U.S. Bessemer plant at 


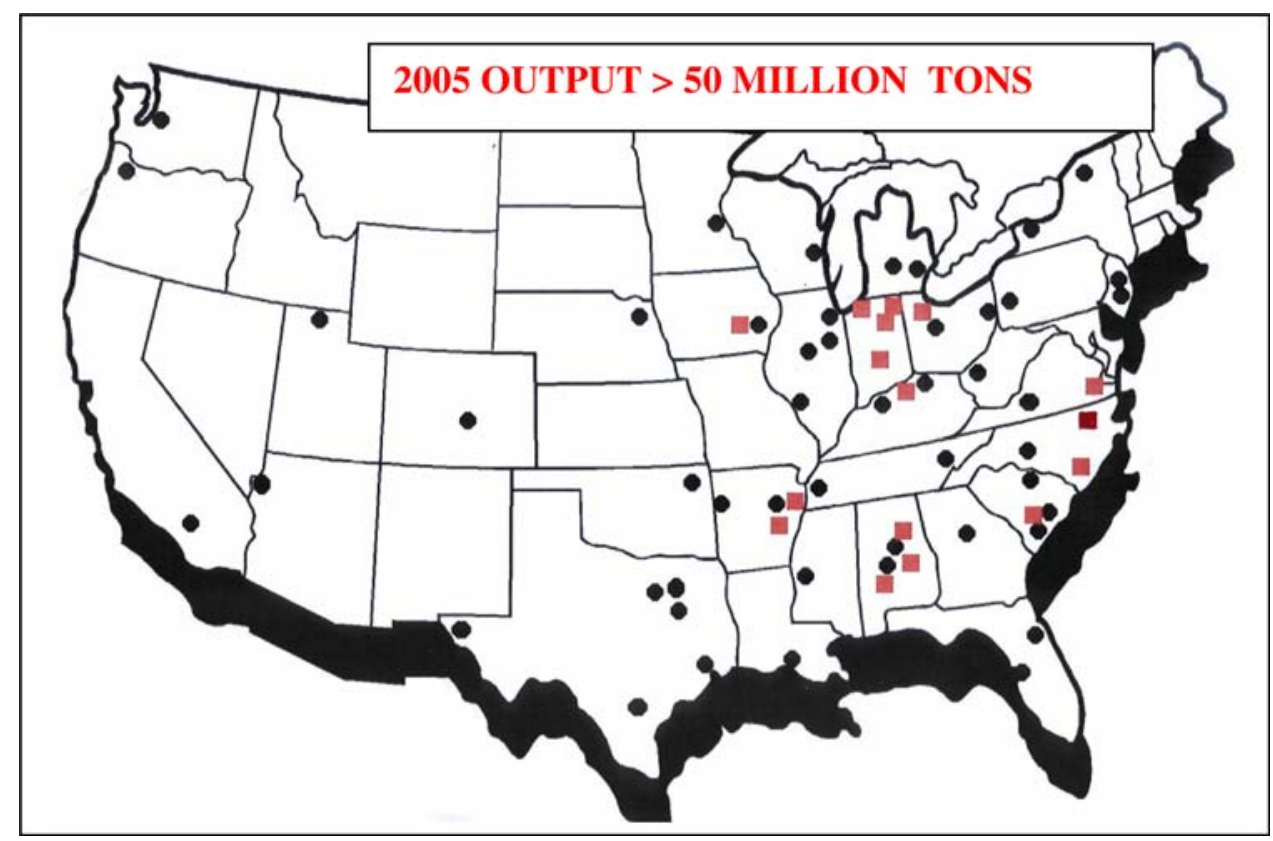

Fig. 16-U.S. EAF mills with casters in 2005.

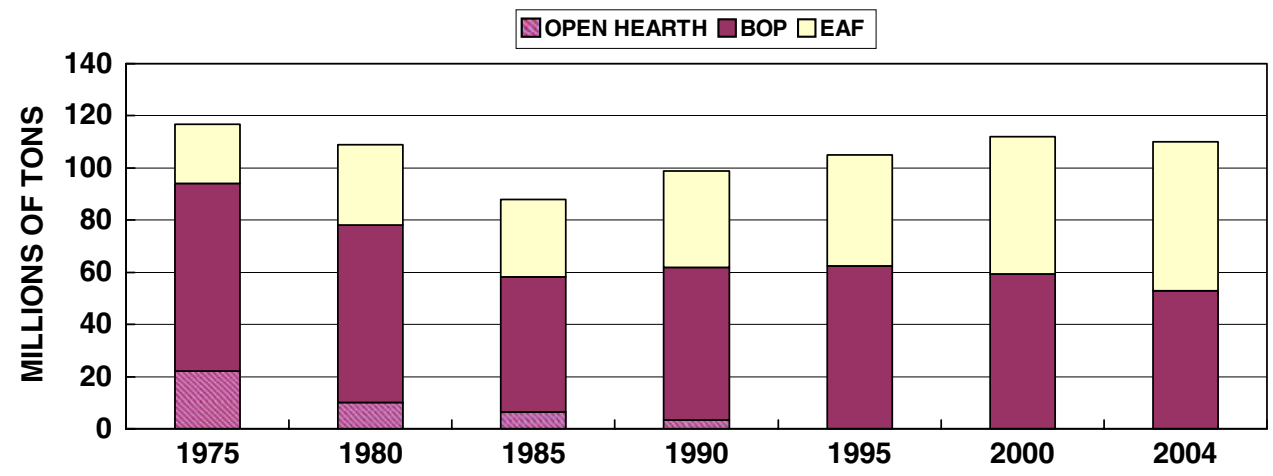

Fig. 17-U.S. raw steel production by process.

Wyandotte, and Chaparral was commissioned exactly 100 years after Carnegies' Edgar Thomson works in Pittsburgh and also in a depression year.

Lasco and Crawfordsville remain pioneering landmarks in the world of steelmaking, and the men that we have singled out in this lecture bear an uncanny behavioral resemblance to the original pioneers in our domestic industry - Carnegie, Holley, Jones, the Fritz brothers, and Schwab. These men also globetrotted to glean ideas from Europe and then improved on them in the United States. Now this approach has been augmented by foreign suppliers with organizations in the United States providing new technologies and working with steel companies to implement them successfully. Because the EAF mills have been profitable, produce quality steel, and have the wherewithal to embrace new technology, is there any justification for formal corporate research facilities? Fundamental process and product research, modeling, and even relevant applied research clearly belong in the domain of academia today.

\section{FOREIGN TECHNOLOGY}

I would be remiss if I did not recognize the contributions of foreign companies to minimill history. Since the 1980s, the dominance of European and Japanese engineering /construction companies in North America has resulted in many innovative furnace, casting, and rolling mill developments. It is hard to imagine a steel world without Concast, Danieli, SMS-Demag, Mannesmann-Demag, Siemens, IHI, NKK Engineering, Mitsubishi, Sumitomo, Fuchs-VAI, and ASEA. Morgan Engineering still proudly flies the U.S. flag at Worcester, MA in bar mill technology. It follows that many world 


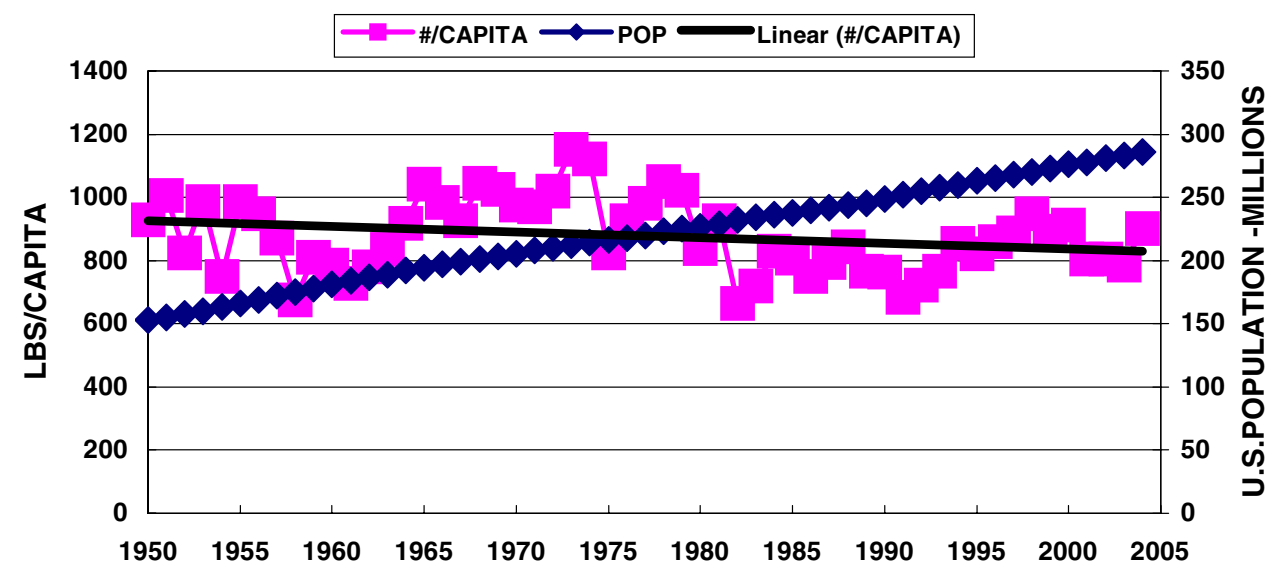

Fig. 18-U.S. per capita consumption of steel.

class minimills incorporating the latest technologies are operating outside the United States. In Mexico, the charging of hot DRI at the Hylsa CSP (now Ternium) is unique. The DDS in Denmark trialed the first shaft for scrap preheating, while DC systems were originally developed at SME in France and Tokyo Steel in Japan. The amazing performance of Badische Stahl Werke has already been mentioned. ${ }^{[12]}$ Northern Italy, with plenty of hydropower, has many productive and innovative EAF plants such as the ISP Arvedi mill at Cremona and the CSP AST mill at Terni for specialty steels. In remote South Africa is the CSP Saldanha Steel mill, with Corex and Midrex units feeding a Conarc process, which is a BOF-EAF twin shell unit. The impact of developments in China, now producing over 350 million tons of steel per year, including production from hot metal Consteel facilities, will be seen in this decade. ${ }^{[22]}$ Technology is available globally. The trick is to select the technology that fits specific regional restraints/opportunities and manage it to minimize raw material and energy costs while maximizing productivity. Quality is a given and labor costs are no longer an issue in North America.

\section{LOOKING AHEAD}

Years ago, I decided that being a futurologist was a lost cause - we cannot extrapolate from the present. In the 1950s, did we ever imagine our present world of space exploration, computers, and cell phones? Further, even as recently as 1999, the IISI experts predicted 25 pct less world steel consumption than actually occurred in $2005 . .^{[23]}$ Where is nanotechnology going? Will the economics of crude oil force North America to exploit their huge proven reserves of oil and tar sands and end our dependence on foreign oil? Only time will tell. One thing is certain in our industry, however. The only sources of iron units are either iron oxide or steel scrap. While scrap will always remain available in North America, it appears that it will have to be supplemented increasingly with alternative iron units in EAF production. The defining process to produce either hot or liquid iron from coal and iron ore as an on-site EAF feedstock is still unresolved, but surely it is only a matter of time.
With a population growing at a rate of over two million a year, and a fairly steady per capita consumption of 850 pounds/annually over the last 50 years (Figure 18), another million tons of steel is needed each year to keep up with domestic demand. Steel is still a vital material in the North American economy, and increasing dependency on imports is not in our best interest. Ultimately, the strength of the industry depends on people, and hundreds have contributed to this minimill saga; they deserve mention but, unfortunately, must remain anonymous at this time. In this Brimacombe lecture, I have recognized the input of only a few outstanding individuals who had both dreams and business acumen. These men emerged without fanfare at a time when the traditional sector of the industry was complacent and even patronizing toward the minimills. Their vision and drive influenced countless men and women whose resiliency and skill have, in turn, kept the North American steel industry globally competitive through difficult times. I am confident that other entrepreneurs will emerge when needed. The old industry has been successfully restructured and the new industry is alive and well and exciting. If only I could sell my soul to the Devil like the legendary Dr. Faustus in exchange for a return visit in a hundred years! Thank you.

\section{ACKNOWLEDGMENTS}

I thank many active and retired colleagues in the North American steel industry for their fascinating personal reminiscences. Unfortunately, there are too many to name individually. I also thank AIST for selecting me to present this lecture in memory of my good friend Keith Brimacombe.

\section{REFERENCES}

1. EAF Steelmaking, Proc. Iron and Steel Division of AIME, J. Sims, ed., Interscience Publishers, New York, NY, 1962, vol. 1, p. 4.

2. C. Briggs: J. Met., 1968, Feb., p. 33. 
3. A. Thalman: Steel Times, 1965, Oct., p. 517.

4. I. Halliday: Continuous Casting, Proc. Iron and Steel Division of AIME, T. Dancy and D. McBride, eds., Interscience Publishers, New York, NY, 1963, p. 3.

5. G.J. Heffernan: private communication.

6. D. McGregor: The Human Side of Enterprise, McGraw-Hill, New York, NY, 1960.

7. E. Spire: A Ladle Treatment for Desulfurizing and Degassing Steel, AIME EF Proc., AIME, Philadelphia, PA, 1951, vol. 9, p. 75.

8. C. Finkl: Degassing-Then and Now, I\&SM, 1981, p. 26.

9. 33 Magazine, 1969, Feb., p. 65.

10. J. Bonestell and R. Weber: EOF Steelmaking, I\&SE, 1985, p. 18.

11. A. Eberle et al.: Start-up and Operating Results of Posco, COREX Unit I\&SE, 1998, p. 25.

12. M. Hamy et al.: EAF Productivity-A Never Ending Story, AIST, Warrendale, PA, 2002, p. 38.

13. R. Preston: American Steel, Prentice Hall, New York, NY, 1991.
14. W. Carlisle, Jr. and C. Ash: Meltshop Optimization at Chaparral Steel, AISE, 1998, p. 41.

15. J.K. Brimacombe: Empowerment with Knowledge, 76th ISS Steelmaking Conf., ISS, 1993, p. 317.

16. J.K. Cotchen, P. Misra, E. Pretorius, and R. Marraccini: AISTech 2004 Proc., p. 1145

17. M. Haissig, G. Fuchs, and W. Auer: MPT Int., 1999, vol. 1, p. 56.

18. A. Manenti and R. Kane: AISTech 2004 Proc., vol. 1, p. 971.

19. J.A. Hansen: Mesabi Nugget-the New Age of Iron, AIST, Warrendale, PA, 2005, p. 149.

20. S. Gull: Gorham Intertech Conf., Atlanta, GA, Nov. 1999.

21. P. Campbell, W. Blejde, R. Mahapatra, and G. Gillen: Start-up and Operating Excellence of the CASTRIP Process at Nucor, Crawfordsville, I\&SM, 2003, p. 15.

22. N. Shimoda, K. Okamoto, and L. Wenzhong: Process Control Technology for Thin Strip Production in Tangshan, China, AIST, Warrendale, PA, 2005, p. 33.

23. I. Christmas: "Short and Medium Term Outlook for Steel Demand," Report on 1999 IISI Annual Conf. in AIST, Dec. 1999, p. 41. 